\title{
Sympósion: Between Synousía and Aphrodísia in the Symbolic Structures That Support the Individual
}

\author{
Ricardo Jesús GG* \\ National Autonomous University of Mexico, Mexico
}

*Corresponding author: García Gómez Ricardo Jesús, UNAM, Cll Tulipanes MZ6 LT8 Ayotla Izcalli Jardines Ayotla EM, México, Tel: 5562212481; Email: richar_9000@hotmail.com

\section{Opinion}

Volume 3 Issue 1

Received Date: February 23, 2020

Published Date: March 13, 2020

DOI: $10.23880 /$ phij-16000140

\section{Abstract}

The moments with which we live in everyday life become elements that allow the search for identity. This is how reality is transformed over time, and the questions that were previously asked are reformulated to the extent of leaving them inactive. In this way, asking about meeting and pleasure under an argument that leads to the understanding of the social in the past and now in the present becomes necessary to understand what some materialistic models take away from the individual: the question for Eros.

Keywords: Love; Desire; Art; Senses; Virtue

\section{The Current Discourse: The Search for Virtue}

The space inhabited by the individual is the great opera. Surrounded by symbolic walls and networks of senses are maintained by the creations of their predecessors: museums, large cathedrals, long halls and epic poems that hide in small brushstrokes in the corners of history. The subject has put the Banquet in a different space: if before the individual "philosopher" wondered about Eros, today the subject is immersed in the gloom of those thoughts.

The idea of "God is dead" that Nietzsche works throughout his works is reconfigured in the conversion of values to a technical life composed of two realities: physical and symbolic, rather, real and virtual. Each narrative framework prior to the individual has allowed him to think of himself in a present that moves away at an accelerated pace from his own biological and historical identity. It would be a mistake to think that moral and ethical presuppositions run in the same direction. Currently, the individual of these two realities faces a series of everyday and unscented facts that lead him to an increasingly less sensible praxis. It is difficult, due to the changes that live, that is sustained under a single ethic. The ethic of cruelty, therefore, begins to be part of its aesthetically busy being. To think of the good is to ask about the virtues. The Aristotelian idea of justice as the most excellent of these virtues no longer works, not at least in a technical modernity that seeks to meet the increasingly high needs of the subject: dreams, stars and temperance have stopped inhabiting the fabric cultural. Of course, if the individual tries to take a break from life he is required to realize that these questions have already been asked and the answers have not given much. The speeches of our young people who accompany Socrates, and that today we can call the current "inhabitants of the future", of course are not the same, but also do not hold on the same ideals. Thinking Eros as such has no place for reality, because the subject is also passionate about sadism and the restrictive freedom that this entails.

With the need to build postulates more in line with what was expected by the 21st century, the subject can allow to experience everything that was previously considered bad, cruel or not subject to beauty: I mean that the individual could not allow falling in love only with the body, because the soul (could we say sensitivity and personality?) was aesthetically beautiful. Thanks to the changes the subject may experience more and more sexually brutal demands. If there is no sexual 


\section{Philosophy International Journal}

education, the person can verses involved in inexperience at the time of being with someone, but later, now that language occupies an important place can make known each of his desires: submission, violence, the politically incorrect ... and not feeling bad.

This discovery of passion and desire as an integral part of Eros can also carry out a personal discovery: although in ancient Greece homosexuality was the most outstanding, this did not allow man, as a masculine gender, to make contact with his sensible part. Today responds in another way: a group of men looking at each other in a circle to discover themselves sensitive to the new demands (already necessary) that are requested in everyday life. Talking then, based on the collective experience of the subjects, helps the individual realize the freedom (perhaps illusory) he has, and taking responsibility becomes increasingly difficult. The whole, based on the social, is now part of the individual responsibility, that is, that everyone contributes to some extent to the responsibility of a single subject. Madness, which was previously disguised through myths, today appears in acclaimed mental disorders that allow the subject to free themselves from Catholic moral chains and subject to religious presuppositions. In spite of this, to get involved with sadistic, cruel, sexist or misogynistic ethics, the individual responds to an ethical symbolic framework that sustains him in everyday life: the monuments and the walls that hold him.

\section{The Meeting of the Interconnected World}

The idea of coming together under the rhetoric and the analysis of a specific topic was diminished by a wave of information that leaves the individual without any argument, because the topic he wants to play turns out to be the subject of many horizontal edges, and depth (such as wondering about beauty itself) is set aside due to the immense information it receives in real life and in the virtual world, where the demands are contrasted and the space for being is replaced by ephemeral satisfaction. In this acceleration the individual, and all their psychological structure are affected by a reality where the symbolic and the meaning are only accessible when it is intended to make them accessible, otherwise they end up impacting life without us being able to realize it.

The desktop has been replaced by the increasingly smaller space that takes the individual from one situation to another, that is, from one conversation to another: there is no longer a dreamlike corridor that gives rise to the possibility of reflection of what Eros understands. The term has been replaced by that of Desidium. The framework that allows the creation of a concept has disintegrated until leaving the individual adrift, only survives with the leftovers of the cultural points that precede it. It is important, at this time, the uncontrolled search to be well, not even with oneself, but with the neo-capitalist society that demands from its individuals the search for individual happiness, being understood as a series of mechanisms that make it known to others who are doing well mentally: that those aesthetic elements that accompany love are inhibited so that the other has the possibility of growth, but the individual as a free subject does not wonder what he understands for happiness and well-being, or simply because of that confusing concept "all right". The elements that support Eros are hidden, and the frameworks that stand in solitude, jealousy, rage, violence, the politically bad are left aside to subtract a materialistic concept of being well: go to the psychologist, the nutritionist, to the neurologist, to the sexologist, to the doctor, to informative talks, ask about ways to leave slavery, surrender, evil. The mystical plane of rhythm and melody, of romance and the Gothic are hidden in literature, cinema, theater (the arts) ... where it is possible and healthy to experience cruel ethics.

The subject is in a perpetual state of inactivity, idleness, of restlessness. Through these mechanisms the individual does not give himself to the possibility of knowing each other and transforming each of these elements that belong to Eros to an aesthetic representation of wanting and wishing. Language is criminalized and expelled from society without us noticing.

\section{The Symbolic Structures in the Circumstance of the Subject}

The drink that accompanied the talk in ancient Greece had an end: the community, society, friends, the whole. The speech of each young, adult, member was towards some deity, and even towards a demon. Deep down, reflection and analysis led to the psychological identity of the individual, because through the talk and the historical search for memory, the intermediate point that united gods and men or, rather, the nature of a utopian ethic was sough that would allow the subjects to be aesthetically beautiful: a very thin line between the pleasant for the community and the grotesque of the interior. It was sought, then, to transform the grotesque into beautiful elements of behavior. They were not suppressed or wanted to criminalize them, but they knew that these elements made the individual part of human nature and the arts. The grotesque, strictly speaking, if it was mastered it could come to light as an aesthetically beautiful cultural element: just like the rose thorn.

Due to acceleration, leisurely behaviors, multiple realities and the transformation of customs, subjects can only access the idea of aesthetics through symbolic frameworks that hide in the material of the circumstance. This is through literature, epic poems, cathedrals, museums, the collective 
experience that materializes in an image, music and, in general, in everything that keeps a sense of the mystical reality of Eros.

If the subject accesses them consciously, either through dialogue or reflection, they can use these elements to understand each other for a moment and breathe, even if it is a light breeze, of what has been called aroma: the return to Eros.

The return to this concept is the return to the breath after having endured, for a prolonged time, this activity, that is, non-breathing. In other words, the return to Eros is to once again have the possibility of being Aphrodite's squire, and to enter into the cruel adventures that this entails, the epic that this of. Because this state, in man, turns out to be sporadic and momentary: it lives and dies normally. Since the desire in Eros is the endless search for one to be well for and with the other, something that is grotesquely worked today rejecting oneself when knowing with grim networks: jealousy, death wishes, fears, phobias, a practical idea of being wrong. The search for Eros, therefore, will be the possibility of knowing oneself, accepting what exists within one and transforming the grotesque into a state of well-being that leads to the interpretation of the beauty that lives within each one [1-11].

\section{References}

1. Byung-Chul H (2009) El aroma del tiempo. Un ensayo filosófico sobre el arte de demorarse. Editor digital:
Titivillus ePub base rl2.

2. Comprende la psicología (2017) Umberto Galimberti. Psicoanálisis, fenomenología y nihilismo. Editorial: Salvat. España.

3. Comprende la psicología (2018) Massimo Recalcati. El psicoanálisis en la sociedad contemporánea. Editorial: Salvat. España.

4. De Sade M (2017) Filosofía del tocador. México: grupo editorial Tomo.

5. Foucault M (1967) Historia de la locura en la época clásica I. México: Fondo de Cultura.

6. Lozano J (1976) Historial del Arte. México: Editorial Continental.

7. Morris D (1996) El zoo humano. Editorial: Penguin Random House. México.

8. Nietzsche III (2011) La genealogía de la moral. España: Editorial Gredos.

9. Nietzsche I (2010) El nacimiento de la tragedia. España: Editorial Gredos

10. Nietzsche I (2010) El caminante y su sombra. España: Editorial Gredos

11. Platón (2015) Diálogos III. Banquete. España: Editorial Gredos.

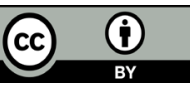

